\title{
Seasonal variations in post-partum plasma progesterone levels and conception in primiparous and multiparous dairy cows
}

\author{
Miriam Rosenberg, Z. Herz, M. Davidson* and Y. Folman \\ Institute of Animal Science, Agricultural Research Organization, \\ The Volcani Center, Bet Dagan, Israel
}

\begin{abstract}
Summary. Progesterone concentrations in peripheral plasma of 18 primiparous and 34 multiparous dairy cows were determined by radioimmunoassay every 4 days, from 10 days post partum until the next conception. The interval from parturition to the first progesterone peak $(>4 \mathrm{ng} / \mathrm{ml}$ plasma) was significantly longer $(P<0.01)$ in primiparous than in multiparous cows. The progesterone concentrations on Days 4-15 of the oestrous cycle were significantly lower $(P<0.025)$ during the summer than in cycles occurring in winter. The conception rate during the summer was lower than in winter. In cows inseminated in summer, conception was related to the shape of the progesterone curve in the cycle preceding insemination.
\end{abstract}

\section{Introduction}

The problem of a reduction in the fertility of dairy cows during the summer months has been widely recognized in recent years (Stott \& Williams, 1962; Dunlap \& Vincent, 1971; Ingraham, Gillette \& Wagner, 1974; Thatcher et al., 1974). The records on artificial insemination in Israel disclose a significant depression in fertility of cows, but not heifers, inseminated during the late summer and early autumn (Heiman, 1972).

Several studies of the effects of continuous heat stress on plasma progesterone concentrations in dairy cows kept in climatic chambers have been published (see Mills, Thatcher, Dunlap \& Vincent, 1972; Abilay, Johnson \& Madan, 1975). However, the information available on the progesterone concentrations in plasma of cows exposed to natural summer conditions is scant. The available data were derived from blood samples obtained either on the day of insemination only (Gwazdauskas, Thatcher \& Wilcox, 1973), or at monthly intervals (Stott \& Wiersma, 1973).

It seemed interesting, therefore, to obtain a complete picture of the plasma progesterone concentrations during all stages of the oestrous cycle of cows exposed to natural summer conditions and to compare them with the levels measured in winter. A further aim was to investigate whether progesterone levels were related to conception during summer and winter and to compare plasma progesterone concentrations in primiparous and multiparous cows during the two seasons as well as during the early post-partum period.

\section{Materials and Methods}

\section{Environmental conditions}

The experiment was conducted during the years 1972-1973 on the Bet Dagan Experiment Farm, which is located on the coastal plain at latitude $32^{\circ} \mathrm{N}$. During the months of November to May (winter), the average maximum temperatures recorded for the location ranged from 18 to $26^{\circ} \mathrm{C}$. During June to October (summer) 1972 and 1973 , average maximum temperatures of $29-32^{\circ} \mathrm{C}$ and a relative humidity of $73-78 \%$ were recorded.

\section{Animals}

The experiment was conducted on 34 multiparous and 18 primiparous Israeli-Friesian dairy cows. The cows were kept in open sheds on concrete slatted floors with adjacent yards having a gravel-

\footnotetext{
* Present address: Hahaklait, Rishon LeZion, Israel.
} 
bedded dirt floor. In the 2 months after parturition the cows were fed $7 \mathrm{~kg}$ hay daily and concentrates ad libitum. From the 3rd month of lactation onwards, the cows were fed 0.5 S.F.U. (Scandinavian Feed Units) per $1 \mathrm{~kg}$ milk in addition to the maintenance requirements. The average body weight, recorded 3 days after parturition, was $557 \pm 13$ (S.E.M.) $\mathrm{kg}$ for the multiparous cows and $423 \pm 8 \cdot 5$ $\mathrm{kg}$ for the primiparous cows. All cows were milked three times daily and weighed twice weekly. The average $4 \%$ fat-corrected milk yield of the multiparous cows during the 1st, 2 nd and 3 rd month after parturition was $22.6 \pm 1 \cdot 1,22.2 \pm 1.0$ and $20.2 \pm 0.9 \mathrm{~kg} /$ day, respectively; the figures for primiparous cows were $13 \cdot 4 \pm 0 \cdot 7,14 \cdot 7 \pm 0 \cdot 6$ and $13 \cdot 6 \pm 0 \cdot 7 \mathrm{~kg} / \mathrm{day}$.

From the 10th day after parturition until the first insemination, the state of the ovaries and uterus was determined by rectal palpation twice weekly. Observation for oestrus was made for 30 min twice daily $(08.00$ and $16.00 \mathrm{~h}$ ) by using a teaser bull with a deviated penis. The cows were inseminated three times during each oestrus. The first insemination, which took place less than $12 \mathrm{~h}$ after detection of oestrus, was followed by two additional inseminations at $12-\mathrm{h}$ intervals. Cows which did not return to service by 45 days after insemination were examined for pregnancy by palpation.

Blood was collected twice weekly from a jugular vein by means of a heparinized evacuated test tube. Blood sampling was started 10 days post partum and was continued until the cow was found to be pregnant. The plasma was stored at $-18^{\circ} \mathrm{C}$ until progesterone determination, which was performed within a few days after blood collection.

\section{Progesterone determination}

Progesterone was determined by radioimmunoassay as described by Lindner, Perel, Friedlander \& Zeitlin (1972). The specificity of the antiserum, Anti-P-11-BSA (which was kindly supplied by Dr Sara Bauminger, Department of Hormone Research, Weizmann Institute of Science, Rehovot, Israel), was described by Lindner et al. (1972). The sensitivity of the assay was $<25 \mathrm{pg}$ progesterone/ tube, i.e. $<0.5 \mathrm{ng} / \mathrm{ml}$ plasma. Within- and between-assay coefficients of variation were $8.1 \%$ and $26.0 \%$, respectively, as determined from five standards in duplicate in each of 15 assays. The mean recovery of crystalline progesterone added to plasma, obtained from a cow on the day of oestrus, was $102 \pm 9 \%$.

\section{Results}

\section{Parity and plasmaprogesterone concentrations}

Low progesterone concentrations were observed in the plasma of all cows up to the time of first ovulation (Table 1). Peripheral progesterone concentrations rose gradually from the time of first ovulation and reached a maximum, lower in primiparous animals, 4-7 days or 8-11 days before the first oestrus. The first appearance of progesterone concentrations exceeding $4 \mathrm{ng} / \mathrm{ml} \mathrm{plasma}$ occurred earlier in multiparous cows. By 30 days post partum, plasma progesterone levels of $4 \mathrm{ng} / \mathrm{ml}$ had been found in only $6 \%$ of the primiparous cows compared with $38 \%$ of the multiparous cows; by 40 days the proportions were $33 \%$ primiparous and $68 \%$ multiparous animals.

The difference in the interval from parturition to the first progesterone peak was accompanied by differences in fertility between primiparous and multiparous cows. The conception rate of the primi-

Table 1. Intervals (mean \pm S.E.M.) from parturition to first ovulation, first oestrus and first progesterone peak (>4 $\mathrm{ng} / \mathrm{ml}$ ) in primiparous and multiparous dairy cows

\begin{tabular}{|c|c|c|c|c|}
\hline \multirow[b]{2}{*}{ Parity } & \multirow{2}{*}{$\begin{array}{c}\text { No. } \\
\text { of } \\
\text { cows }\end{array}$} & \multicolumn{3}{|c|}{ Interval (days) from parturition to: } \\
\hline & & $\begin{array}{c}\text { First } \\
\text { ovulation }\end{array}$ & $\begin{array}{c}\text { First observed } \\
\text { oestrus }\end{array}$ & $\begin{array}{l}\text { First proges- } \\
\text { terone peak }\end{array}$ \\
\hline Multiparous & 34 & $21 \cdot 7 \pm 1 \cdot 1^{*}$ & $38.9 \pm 2.9$ & $37 \cdot 6 \pm 2 \cdot 6^{* *}$ \\
\hline Primiparous & 18 & $27 \cdot 0 \pm 2 \cdot 2^{*}$ & $40.6 \pm 3.6$ & $51 \cdot 6 \pm 4 \cdot 7^{* *}$ \\
\hline
\end{tabular}

Significantly different $* P<0.05, * * P<0.01$. 
parous cows inseminated 45-70 days after parturition was only 3 out of 11 animals inseminated $(27 \%$ ) compared with a rate of $55 \%$ in 29 multiparous cows inseminated during the same period post partum. The difference was not statistically significant because of the small number of cows in each group.

\section{Season and progesterone levels}

The progesterone concentrations found in plasma 8-19 days before oestrus were significantly lower during the summer months than in the winter (Text-fig. 1). The average progesterone concentrations presented in the figure were computed from all complete cycles which occurred between Days 30 and 120 post partum in multiparous cows and between Days 40 and 120 post partum in primiparous cows. The first cycle post partum of primiparous cows was not included because progesterone concentrations in this cycle were significantly lower than in the following cycles (data not shown).

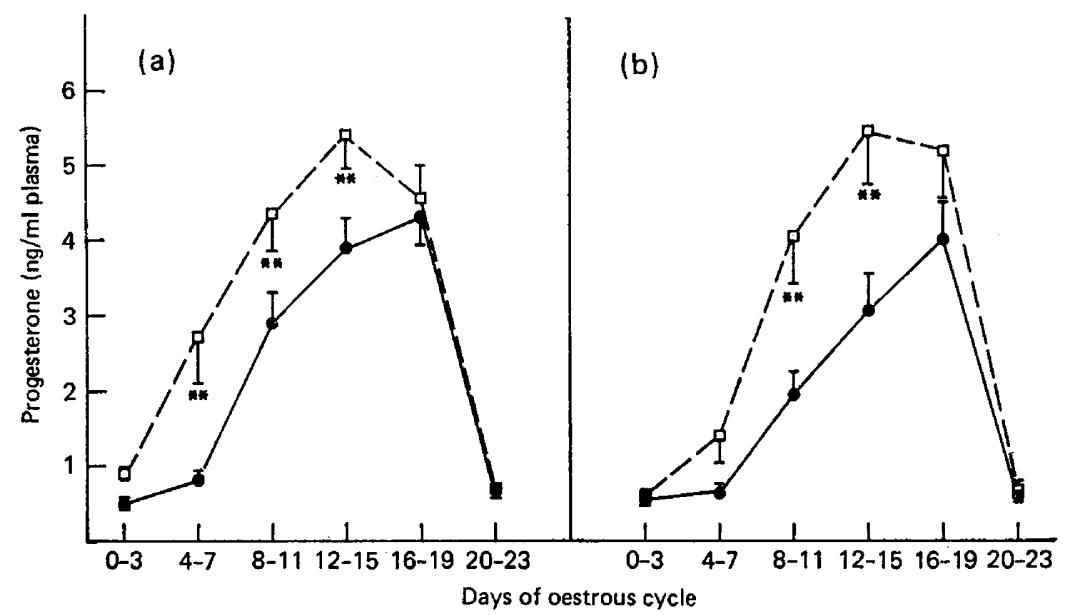

Text-fig. 1. Plasma progesterone concentrations (mean \pm S.E.M.) during the cycles of (a) multiparous and (b) primiparous dairy cows in summer $(\bullet, 14$ and 12 cycles of 10 multiparous and 7 primiparous cows respectively) and winter $(\square, 21$ and 14 cycles of 16 multiparous and 9 primiparous cows respectively). Values significantly different $(P<0.025, t$ test $)$ from those occurring in summer are indicated with asterisks.

Cows inseminated in summer had significantly lower conception rates than cows inseminated in winter (Table 2). During the summer, the progesterone concentrations of cows which conceived at the first insemination reached their peak within 7 days before insemination. Ineffective inseminations on the other hand, were preceded by cycles in which the peak progesterone concentration was reached 8-11 days before insemination (Table 3). The point biserial correlation coefficient between the occurrence of conception after the first insemination in summer and the difference in plasma progesterone concentrations between Days 4-7 and 8-11 before insemination was $r=0.49(P \leqslant 0.01)$. No correlation was observed between conception and the changes in progesterone concentrations during the luteal phase preceding insemination in cows inseminated in winter (Table 3).

Table 2. Conception rate of dairy cows (multiparous and primiparous) inseminated in summer and winter

\begin{tabular}{llll}
\hline & & Summer & Winter \\
\hline All inseminations & No. of inseminations & 37 & 44 \\
& Conception rate (\%) & $51^{*}$ & 75 \\
\multirow{3}{*}{ First inseminations } & No. of inseminations & 26 & 26 \\
& Conception rate (\%) & $46^{*}$ & 77 \\
\hline
\end{tabular}

* Significantly different from conception rate in winter, $P \leqslant 0.05\left(\chi^{2}\right.$ test). 
Table 3. The relationship between conception from first insemination and plasma progesterone concentrations at the end of the luteal phase preceding insemination of multiparous and primiparous cows (no. in parentheses) during summer and winter

\begin{tabular}{lccccc}
\hline & \multicolumn{3}{c}{ Plasma progesterone concentration (ng/ml) } \\
\cline { 2 - 3 } $\begin{array}{c}\text { Days } \\
\text { preceding } \\
\text { inseminations }\end{array}$ & Fertile (12) & Infertile (14) & & Fertile (20) & Infertile (6) \\
\cline { 2 - 3 } $8-11$ & $2.9 \pm 0.4$ & $3.5 \pm 0.5$ & & $5.3 \pm 0.6$ & $5.5 \pm 1.4$ \\
$4-7$ & $3.8 \pm 0.4$ & $3.0 \pm 0.5$ & & $4.6 \pm 0.5$ & $5.0 \pm 0.8$ \\
Difference & +0.9 & -0.5 & & -0.7 & -0.5 \\
& $\pm 0.2^{*}$ & $\pm 0.4 *$ & & \pm 0.4 & \pm 0.6 \\
\hline
\end{tabular}

Values are mean \pm S.E.M.

* Significantly different, $P \leqslant 0.01$.

\section{Discussion}

Considerable variability in progesterone concentrations during the post-partum period has been reported in the literature (Pope, Gupta \& Munro, 1969; Donaldson, Bassett \& Thorburn, 1970; Robertson, 1972), but no comparison between the progesterone levels of primiparous and multiparous cows has been published. The present study indicates that peak luteal phase progesterone concentrations exceeding $4 \mathrm{ng} / \mathrm{ml}$ plasma are attained later in primiparous than in multiparous cows (Table 1). This difference was also apparent (Text-fig. 1) when calving had occurred during the summer months. Very low plasma progesterone concentrations during the first cycles post partum and low conception rates at the first post-partum oestrus have also been reported for primiparous beef heifers (Corah, Quealy, Dunn \& Kaltenbach, 1974). In view of these results the recommendation (Olds \& Cooper, 1970; Machnai \& Kali, 1971; Whitmore, Tyler \& Casida, 1974) to inseminate cows after a post-partum interval of $\mathbf{4 5}$ days should be reconsidered for primiparous animals.

The effect of exposure to high environmental temperatures on the peripheral concentrations of progesterone have been investigated by several workers concerned with the problems of summer infertility in cattle. Relatively high environmental temperatures on the day of insemination are correlated with progesterone concentrations which are higher than those usually observed on the day of oestrus (Gwazdauskas et al., 1973). Mills et al.(1972) found a significant increase in plasma progesterone levels in heifers which had been exposed to continuous heat stress for 3 days. Chronic exposure to heat $\left(33.5^{\circ} \mathrm{C}\right)$, for the duration of 2 oestrous cycles under controlled laboratory conditions, increased plasma progesterone concentrations during most of the first cycle and the first part of the second cycle (Abilay et al., 1975). On the other hand, the average monthly plasma progestin concentrations of cows exposed to normal summer conditions in Arizona were reported to be lower than the levels observed in cows which were kept under cooled shades on the same location (Stott \& Wiersma, 1973). Because the plasma samples in this experiment were obtained only once a month, the progesterone concentrations on different days of the oestrous cycle could only be estimated, but the cooled cattle were believed to have higher progesterone levels at each stage of the luteal phase of the cycle.

In the present study the change in temperatures to which the animals were exposed occurred gradually, and not drastically as in the experiments of Abilay et al. (1975). Furthermore, the high temperatures to which the cows were exposed during the day decreased considerably during the night. Under these conditions a lower peripheral progesterone concentration was observed during most of the luteal phase of oestrous cycles occurring during the summer months (Text-fig. 1) and, from the shape of the progesterone curve, the rate of development of the corpus luteum appears to be slower during the summer than in winter. In summer, the progesterone concentration in cycles preceding fertile inseminations reached a peak near the time of insemination, while those in cows which did not conceive began to decrease as early as 8-11 days beforeinsemination. It has been previously suggested 
(Folman, Rosenberg, Herz \& Davidson, 1973; Corah et al., 1974) that the level of progesterone during the luteal phase of the cycle preceding the first insemination may be positively related to conception. It is possible that in summer, when the levels of progesterone are lower than in winter, the stage of the oestrous cycle in which luteolysis occurs may be important for the occurrence of conception.

We thank Dr S. Bauminger of the Hormone Research Department, The Weizmann Institute of Science, Rehovot, Israel, for the antiprogesterone serum; Mrs C. Hefer and the staff of the Bet Dagan Experiment Farm for skilled technical assistance. This paper is contribution No. 226-E (1976 Series) from the A.R.O., The Volcani Center, Bet Dagan, Israel.

\section{References}

AbIlay, T.A., Johnson, H.D. \& Madan, M. (1975) Influence of environmental heat on peripheral plasma progesterone and cortisol during the bovine estrous cycle.J. Dairy Sci. 58, 1836-1840.

Corah, L.R., QUealy, A.P., DUNN, T.G. \& Kaltenbach, C.C. (1974) Prepartum and postpartum levels of progesterone and estradiol in beef heifers fed two levels of energy. J. Anim. Sci. 39, 380-385.

Donaldson, L.E., Bassetr, J.M. \& Thorburn, G.D. (1970) Peripheral plasma progesterone concentrations of cows during puberty, oestrous cycles, pregnancy and lactation, and the effects of undernutrition or exogenous oxytocin on progesterone concentration. J. Endocr. 48, 599-614.

DuNlaP, S.E. \& VINCENT, C.K. (1971) Influence of postbreeding thermal stress on conception rate in beef cattle. J. Anim. Sci.32, 1216-1218.

Folman, Y., Rosenberg, M., Herz, Z. \& Davidson, M. (1973) The relationship between plasma progesterone concentrations and conception in postpartum dairy cows maintained on two levels of nutrition.J. Reprod. Fert. 34, 267-278.

Gwazdauskas, F.C., Thatcher, W.W. \& Wilcox, C.J. (1973) Physiological, environmental, and hormonal factors at insemination which may affect conception. J. Dairy Sci.56,873-877.

Heiman, M.M. (1972) Differential bioclimatic influence on the fertility of bulls, cows and heifers. In Proc. 7th Int. Congr. Anim. Reprod. \& A.I., Munich 3, 2007-2010.

Ingraham, R.H., Gillette, D.D. \& Wagner, W.D. (1974) Relationship of temperature and humidity to conception rate of Holstein cows in subtropical climate. J. Dairy Sci.57, 476-481.

Lindner, H.R., Perel, E., Friedlander, A. \& Zeitlin, A. (1972) Specificity of antibodies to ovarian hormones in relation to the site of attachment of the steroid bapten to the peptide carrier. Steroids 19 , 357-375.

MachNaI, B. \& Kal, J. (1971) Early insemination after parturition in three dairy herds. Refuah Vet. 28, 112-115.

Mills, A.G., Thatcher, W.W., Dunlap, S.E. \& VINCENT, C.K. (1972) Influence of postbreeding thermal stress on peripheral plasma progestin concentrations in heifers. J. Dairy Sci. 55, 400-401, Abstr.

OLDS, D. \& COOPER, T. (1970) Effect of postpartum rest period in dairy cattle on the occurrence of breeding abnormalities and on calving intervals. J. Am. vet. Med. Ass. 157,92-97.

Pope, G.S., Gupta, S.K. \& Munro, I.B. (1969) Progesterone levels in the systemic plasma of pregnant, cycling and ovariectomized cows. J. Reprod. Fert. 20, 369-381.

ROBERTSON, H.A. (1972) Sequential changes in plasma progesterone in the cow during the estrous cycle, pregnancy, at parturition and post partum. Can. J. Anim. Sci. 52, 645-658.

StotT, G.H. \& Wiersma, F. (1973) Climatic thermal stress, a cause of hormonal depression and low fertility in bovine. Int. J. Biometeor. 17, 115-122.

Stotr, G.H. \& Williams, R.J. (1962) Causes of low breeding efficiency in dairy cattle associated with seasonal high temperatures. J. Dairy Sci. 45, 13691375.

Tharcher, W.W., Gwazdauskas, F.C., Wilcox, C.J., Toms, J., Head, H.H., Buffington, D.E. \& FredRIKSSON, W.B. (1974) Milking performance and reproductive efficiency of dairy cows in an environmentally controlled structure. J. Dairy Sci. 57, 304-307.

Whitmore, H.L., Tyler, W.J. \& CASida, L.E. (1974) Effects of early postpartum breeding in dairy cattle. J. Anim. Sci. 38, 339-346. 